\title{
Measuring Efficiency of Selected Agriculture Commodities
}

\author{
Tanushree Sharma, Puja Sharma
}

\begin{abstract}
It has been observed that there is high fluctuation in eight agricultural commodities. In this study price discovery and causality has been studied in select six commodities out of the above mentioned eight commodities. We could not find sufficient data for cardamom and mentha oil. The commodities selected are chana,soyabean,soya oil,guargum,potato and pepper. The purpose is to study causality and price discovery in selected agri commodities.

Design/methodology/approach - National Commodity Exchange of India (NCDEX) website. We could not found any cointegration between guargum and potato future and spot price. Single cointegration vector was being identified between spot and future prices of chana, Soyabean, soyarefined and Pepper. To measure causal nexus between future and spot price of the selected agricultural commodity Vector error correction model (VECM) is employed. This is consistent with market efficiency. Finally, impulse response function and Variance decomposition is used to see price discovery in these four commodities.

Findings - The investigation shows that future leads to spot in case of soyabean and soya oil. Whereas in case of chana and pepper we found bi-directional relationship. As per Impulse response function and Variance decomposition we found future price leads in case of Chana,Soyaoil,Soyabean and pepper and performs price discovery function.
\end{abstract}

Keywords : Agriculture commoditities, iCausality Price discovery JEL Classification: C13, G13, G14,

\section{INTRODUCTION}

In India, More than $58.4 \%$ of the total population survives on agriculture sector.This sector contributes approximately one-fifth of the total gross domestic product. Agricultural commodities are being categorized into two parts. Soft commodities which create huge volatility in a few agriculture commodities in the short term. These commodities are pepper, chana, guar gum, soya oil,corn, wheat, soybean, soybean oil, sugar. Hard commodities are mined from the ground like gold, oil, Aluminum. Thus we can say that India is fully richer in the agricultural sector. This shows that commodities are considered as a separate asset compare to all others.

As we all know that there is high fluctuation in the prices of the agricultural commodity in India. But we don't know the exact reasons for the price hike. Uncertain fluctuations in commodities create a major concern for

Revised Manuscript Received on October 31, 2019.

* Correspondence Author

Tanushree Sharma *, Department of Commerce, School of Business \& Commerce, Manipal University Jaipur, India. Email: tanushree.sharma@jaipur.manipal.edu

Puja Sharma, Department of Commerce, School of Business \& Commerce, Manipal University Jaipur, India. Email: puja2487@ gmail.com policy makers. It is not an easy task to find out what is the reason for the increasing rate of commodities.

India rapidly increased in trading of different kinds of commodities. In 1939, there was more than 300 commodity exchange in India offering derivatives contracts on commodities like turmeric, cumin seed, chili, sugar, pepper, cotton, jute, oilseeds, etc. It has witnessed that commodity prices are fluctuating which led economists to theorize about the changes in commodities. Rising commodity prices will hit the poor very badly, so food prices are of major concern. In developing countries, the price elasticity for food is very high. The impact of speculation on the prices of agricultural commodities has been studied thoroughly in the literature.

\section{REVIEW OF LITERATURE}

\begin{tabular}{|c|c|c|c|c|}
\hline 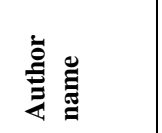 & 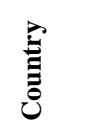 & 己. & 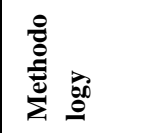 & 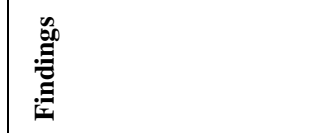 \\
\hline \begin{tabular}{|c|} 
Biswas et \\
al.[2]
\end{tabular} & India & $\begin{array}{l}\text { MCX } \\
\text { Gold, } \\
\text { MCX } \\
\text { Silver } \\
\text { MCX } \\
\text { Crude }\end{array}$ & $\begin{array}{c}\text { Correlatior } \\
\text {,Granger } \\
\text { Causality }\end{array}$ & $\begin{array}{l}\text { Granger causality was } \\
\text { present and it } \\
\text { supported } \\
\text { SIH(Sequential } \\
\text { information arrival } \\
\text { hypothesis) }\end{array}$ \\
\hline Kumar[5] & India & Pepper & $\begin{array}{l}\text { Co-integra } \\
\text { ion VECN }\end{array}$ & $\begin{array}{l}\text { Impact of Futures } \\
\text { lprices are much larger } \\
\text { than spot prices. }\end{array}$ \\
\hline \begin{tabular}{|l|} 
Thiyagaraj \\
an et al. [7]
\end{tabular} & India & $\begin{array}{c}\text { Energy } \\
\text { index } \\
\text { Metal } \\
\text { index, } \\
\text { Agri } \\
\text { index }\end{array}$ & $\begin{array}{l}\text { VECM } \\
\text { Model, } \\
\text { Granger } \\
\text { causality } \\
\text { Test }\end{array}$ & $\begin{array}{l}\text { Granger causality test } \\
\text { indicates that there is } \\
\text { short and long run } \\
\text { causal relationship } \\
\text { between the two } \\
\text { indices. }\end{array}$ \\
\hline $\begin{array}{l}\text { Rao et } \\
\text { al.[8] }\end{array}$ & India & Chilli & $\begin{array}{l}\text { Conceptua } \\
\text { and } \\
\text { empirical } \\
\text { methodolo } \\
\text { gy }\end{array}$ & $\begin{array}{l}\text { The farmers. Absence } \\
\text { of market players } \\
\text { allows contracts to be } \\
\text { exposed to price } \\
\text { manipulation. }\end{array}$ \\
\hline
\end{tabular}




\begin{tabular}{|c|c|c|c|c|}
\hline $\begin{array}{c}\text { Sharma et } \\
\text { al.[9] }\end{array}$ & India & $\begin{array}{l}\text { Guar } \\
\text { seed }\end{array}$ & $\begin{array}{l}\text { GARCH } \\
\text { model }(1,1) \\
\text { Granger } \\
\text { causality } \\
\text { test }\end{array}$ & $\begin{array}{l}\text { A positive relationship } \\
\text { is found among } \\
\text { unexpected futures } \\
\text { trading volume and } \\
\text { spot returns volatility. }\end{array}$ \\
\hline $\begin{array}{l}\text { Malhot } \\
\text { ra et } \\
\text { al.-[6] }\end{array}$ & India & $\begin{array}{l}\text { Guar } \\
\text { seed }\end{array}$ & $\begin{array}{l}\text { Granger } \\
\text { causality } \\
\text { VECM } \\
\text { Model }\end{array}$ & $\begin{array}{l}\text { VECM results } \\
\text { indicates } \\
\text { unidirectional flow of } \\
\text { information from the } \\
\text { futures to spot } \\
\text { market. }\end{array}$ \\
\hline $\begin{array}{l}\text { Chakrab } \\
\text { orty et } \\
\text { al.[3] }\end{array}$ & $\begin{array}{l}\text { Indi } \\
\text { a }\end{array}$ & \begin{tabular}{|l|} 
Barley \\
Maize \\
Mustard \\
seed \\
pepper
\end{tabular} & $\begin{array}{l}\text { VAR, } \\
\text { GARCH(1,1 } \\
\text { ) }\end{array}$ & $\begin{array}{l}\text { The study result } \\
\text { indicates that } \\
\text { unexpected trading } \\
\text { volume causes spot } \\
\text { price volatility for } \\
\text { selected agriculture } \\
\text { commodities. }\end{array}$ \\
\hline $\begin{array}{c}\text { Tarun } \\
\text { Soni }[11]\end{array}$ & India & \begin{tabular}{|c|} 
Maize, \\
Chana \\
Soybean \\
.Wheat
\end{tabular} & \begin{tabular}{|c|} 
VECM \\
Model \\
Granger \\
causality \\
Wald test
\end{tabular} & 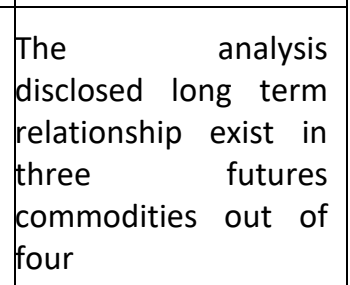 \\
\hline $\begin{array}{c}\text { Kumar et } \\
\text { al.[12] }\end{array}$ & India & \begin{tabular}{|c|} 
MCX \\
COMD \\
EX \\
MCXA \\
GRI \\
MCXE \\
NERGY \\
MCXME \\
TAL
\end{tabular} & $\begin{array}{c}\text { VECM } \\
\text { (EGARCH) }\end{array}$ & 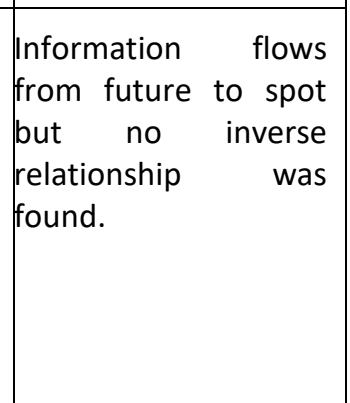 \\
\hline $\begin{array}{c}\text { Swaroop et } \\
\text { al.[4] }\end{array}$ & India & $\begin{array}{c}\text { Nifty } \\
\text { index } \\
\text { futures }\end{array}$ & $\begin{array}{l}\text { Linear } \\
\text { regression } \\
\text { model } \\
\text { Chow test } \\
\text { Garch }\end{array}$ & $\begin{array}{l}\text { There is difference } \\
\text { in pre and post } \\
\text { data. }\end{array}$ \\
\hline $\begin{array}{c}\text { Ranganath } \\
\text { an et } \\
\text { al.[13] }\end{array}$ & India & Soybean & $\begin{array}{c}\text { Cointegrati } \\
\text { on } \\
\text { GARCH }\end{array}$ & $\begin{array}{l}\text { Market is inefficient } \\
\text { in the short run and } \\
\text { in long run market } t \\
\text { s unbiased for } \\
\text { soyabean. }\end{array}$ \\
\hline $\begin{array}{l}\text { Rajendra } \\
\text { et al.[1] }\end{array}$ & India & $\begin{array}{c}\text { Agricult } \\
\text { ural } \\
\text { commo } \\
\text { dities }\end{array}$ & Conceptual & $\begin{array}{l}\text { The supply and } \\
\text { demand are the key } \\
\text { factors for volatility } \\
\text { in agriculture } \\
\text { commodities. }\end{array}$ \\
\hline $\begin{array}{c}\text { Sharma[10 } \\
]\end{array}$ & India & Pepper & $\begin{array}{l}\text { GARCH } \\
\text { Granger } \\
\text { causality }\end{array}$ & $\begin{array}{l}\text { OI, unexpected } \\
\text { open interest are } \\
\text { significant to explain } \\
\text { volatility in spot } \\
\text { price of pepper. }\end{array}$ \\
\hline
\end{tabular}

\section{METHODOLOGY AND DATA}

Daily closing prices of spot and futures of Soyabean, Chana ,soyarefined, Guargum, Potato and Pepper are used as secondary data. The data set has been comprised from November 2006 to April 2016 . Near month futures prices are used for the study as they are mostly traded as compared to next month and far month future contracts. Data has been retrieved from the National Commodity Exchange of India(NCDEX) website.

\section{EMPIRICAL RESULTS AND DISCUSSIONS}

Johansen's Cointegration test is used to examine the long-run relationship between spot and future prices and its results are presented in Table-II. No cointegration was found between spot and future price of potato and Guar gum(refer Table I).

Table-I - Johansen's Cointegration Test Results

\begin{tabular}{|c|c|c|c|c|c|}
\hline Commodity & $\begin{array}{l}\text { Hypothesiz } \\
\text { ed } \\
\text { No. of } \\
\text { CE(s) }\end{array}$ & $\begin{array}{l}\text { Eigen } \\
\text { Value }\end{array}$ & $\begin{array}{c}\text { Trace } \\
\text { Statistic }\end{array}$ & $\begin{array}{c}\text { Critica } \\
1 \\
\text { Value }\end{array}$ & Prob.** \\
\hline \multirow{2}{*}{ Chana } & None & 0.059178 & 9.629463 & 15.49471 & 0.0203 \\
\hline & At most 1 & 0.006789 & 0.96729 & 3.841466 & 0.3254 \\
\hline \multirow{2}{*}{ Soyabean } & None * & 0.030664 & 51.52274 & 15.49471 & 0.0000 \\
\hline & At most 1 & 0.001179 & 1.879826 & 3.841466 & 0.1704 \\
\hline \multirow{2}{*}{ Soya Oil } & None* & 0.040237 & 60.04337 & 15.49471 & 0.0000 \\
\hline & At most 1 & 0.000312 & 0.452581 & 3.841466 & 0.5011 \\
\hline \multirow{2}{*}{ Guargum } & None * & 0.064171 & 144.7169 & 15.49471 & 0.0001 \\
\hline & At most $1 *$ & 0.02456 & 39.46387 & 3.841466 & 0.0000 \\
\hline \multirow{2}{*}{ Potato } & None & 0.019789 & 12.45223 & 14.2646 & 0.0948 \\
\hline & At most $1^{*}$ & 0.00698 & 4.363562 & 3.841466 & 0.0367 \\
\hline \multirow{2}{*}{ Pepper } & None * & 0.065144 & 109.197 & 15.49471 & 0.0001 \\
\hline & At most 1 & $1.22 \mathrm{E}-06$ & 0.00198 & 3.841466 & 0.9611 \\
\hline
\end{tabular}
0.05 level

*MacKinnon-Haug-Michelis(1999)p-values

To further study long run relationship VAR model is applied , impulse response function and variance decomposition are used to further elaborate relationship for chana, Soyabean, soyarefined and Pepper future and spot prices. Figures illustrates the estimated impulse response functions for ten days period. The graphs of impulse response functions depicted in Figure I. Figure outline ten periods ahead forecasting for chana,Soyabean, soyarefined, and Pepper. 

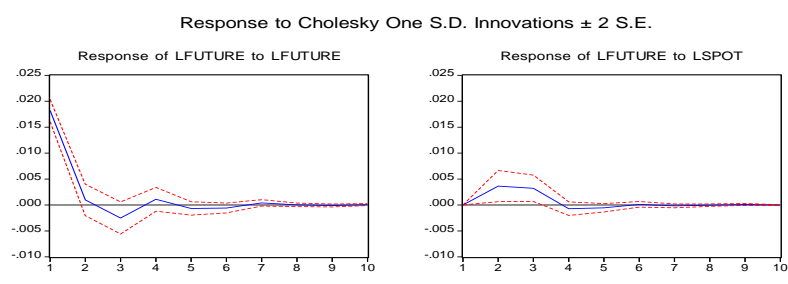

Response of LSPOT to LFUTURE
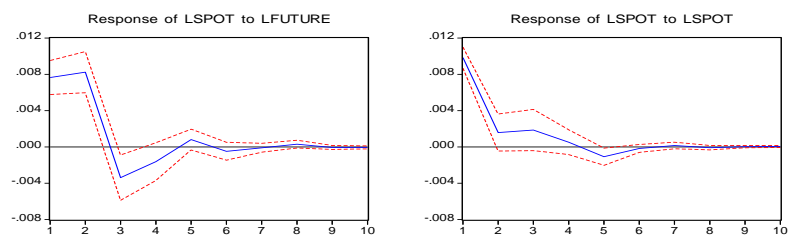

Fig. I -Impulse Response Function of Chana-

Table II: Variance decomposition of Chana

\begin{tabular}{|c|c|c|c|c|c|}
\hline \multicolumn{3}{|c|}{$\begin{array}{l}\text { Panel A: Variance } \\
\text { Decomposition of } \\
\text { LSPOT: }\end{array}$} & \multicolumn{3}{|c|}{$\begin{array}{l}\text { Panel B:Variance } \\
\text { Decomposition of } \\
\text { LFUTURE: }\end{array}$} \\
\hline Period & LFUTURE & LSPOT & $\begin{array}{c}\text { Perio } \\
\text { d }\end{array}$ & LFUTURE & LSPOT \\
\hline 1 & 37.66341 & 62.33659 & 1 & 100 & 0 \\
\hline 10 & 57.53465 & 42.46535 & 10 & 93.30247 & 6.697527 \\
\hline
\end{tabular}

The shape of the impulse response graphs narrate that spot market has a larger response to one standard deviation shocks to the future price than the future responses to spot vicissitude. Initially spot price fluctuated for 4 days when there is shock to future prices. It remain constant from 4 to 10th day Relatively, the response of spot price is greater than the response of future prices. From above analysis we can say that future price leads more as compared to spot price.

Panel A of Table II shows the forecast error variance decomposition of spot return. Initially a high percentage $(62.33 \%)$ of its total forecast error variance is explained by itself. After that it decreased to $44.03 \%$ in $2^{\text {nd }}$ period. Later on it decreased but at a very slow pace. However, in the first period of the forecasting horizon, $37.66 \%$ variation in the forecast error of spot market is explained by the futures market. After that it increased to $55.96 \%$ in $2^{\text {nd }}$ period and later on increased at decreasing rate. This indicates that percentage of the forecast error variance in spot price is due to futures prices is more. In other words, the futures prices lead to spot prices. Similarly, Panel B of Table II reports the forecast error variance decomposition of futures returns. Throughout the forecast period, it explains a high level of forecast error variance of itself. Initially, it explains $100 \%$ variation in its forecast error, but after that it shows a decreasing trend. Only a small percentage changes in forecast error of futures market is by the spot market, though over the period of time it shows an escalating trend, but the rate of increase is very low. This indicates that futures prices lead the spot prices in Chana. The shape of the impulse response graphs discloses that spot market has a larger response to one standard deviation shocks to the future price than the future responses to spot innovations
.Initially the response of spot price to shocks to futures prices declined till $4^{\text {th }}$ day The response of spot price is higher than the response of future prices comparatively. Thus, it can be concluded from the analysis that future price leads in Soyabean.

\section{Table - III : Variance Decomposition of Soyabean}

\begin{tabular}{|c|c|c|c|c|c|}
\hline \multicolumn{2}{|c|}{$\begin{array}{c}\text { Panel A: Variance } \\
\text { Decomposition of } \\
\text { LSPOT: }\end{array}$} & \multicolumn{3}{c|}{$\begin{array}{c}\text { Panel B:Variance } \\
\text { Decomposition of } \\
\text { LFUTURE: }\end{array}$} \\
\hline \multicolumn{2}{|c|}{} & \multicolumn{3}{c|}{} \\
\hline Period & LFUTURE & LSPOT & Period & LFUTURE & LSPOT \\
\hline 1 & 23.93362 & 76.06638 & 1 & 100 & 0 \\
\hline 10 & 31.82939 & 68.17061 & 10 & 99.07571 & 0.924289 \\
\hline
\end{tabular}

Panel A of Table III shows the forecast error variance decomposition of spot return. Initially a high percentage $(76.07 \%)$ of its total forecast error variance is explained by itself in spot price. After that it decreased and then remained constant. However, in the first period of the forecasting horizon $23.93 \%$ variation in the forecast error of spot market is explained by the futures market. Panel $B$ of Table III reports the forecast error variance decomposition of futures returns. Throughout the forecast period, it explains a high level of forecast error variance of itself. At the initial period, it explains $100 \%$ variation in its forecast error, but after that it shows a decreasing trend. However, only a small percentage changes in forecast error of futures market is explained by the spot market,
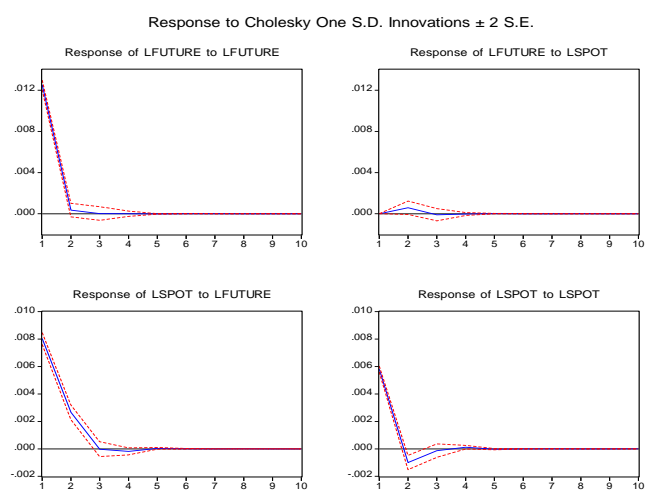

Fig. III. Impulse Response Function of Soyaoil

It is evident from the shape of the impulse response graphs that spot market has a larger response to one standard deviation shocks to the future price than the future responses to spot innovations. Initially the response of spot price to shocks to futures prices declined till $3^{\text {rd }}$ day .It remain almost constant from 3 to $10^{\text {th }}$ day. On the other hand, response of futures price to shocks to spot prices increased a bit initially declined till $4^{\text {th }}$ period and then remained constant. The response of spot price is higher than the response of future prices comparatively. Thus, it can be concluded from the analysis that future price leads in Soya Oil. 
Table - V : Variance Decomposition of Soya Oil

\begin{tabular}{|c|c|c|c|c|c|}
\hline \multicolumn{2}{|c|}{$\begin{array}{c}\text { Panel A: Variance } \\
\text { Decomposition of } \\
\text { LSPOT: }\end{array}$} & \multicolumn{3}{c|}{$\begin{array}{c}\text { Panel B:Variance } \\
\text { Decomposition of } \\
\text { LFUTURE: }\end{array}$} \\
\hline Period & LFUTURE & LSPOT & Period & LFUTURE LSPOT \\
\hline 1 & 65.69934 & $\begin{array}{c}34.3006 \\
6\end{array}$ & 1 & 100 & 0 \\
\hline 10 & 67.35762 & $\begin{array}{c}32.6423 \\
8\end{array}$ & 10 & 99.77947 & $\begin{array}{c}0.22053 \\
3\end{array}$ \\
\hline
\end{tabular}

Initially a low percentage $(34.30 \%)$ of its total forecast error variance is explained by itself in case of Soyaoil. After that it decreased to $32.63 \%$ and then remained constant . However, in the first period of the forecasting horizon $65.69 \%$ variation in the forecast error of spot market is explained by the futures market. In other words, the futures prices lead to spot prices. Similarly, Panel B of Table $V$ reports the forecast error variance decomposition of futures returns. it shows an increasing trend, but the rate of increase is very low. This indicates that in Soyaoil futures prices lead the spot prices.

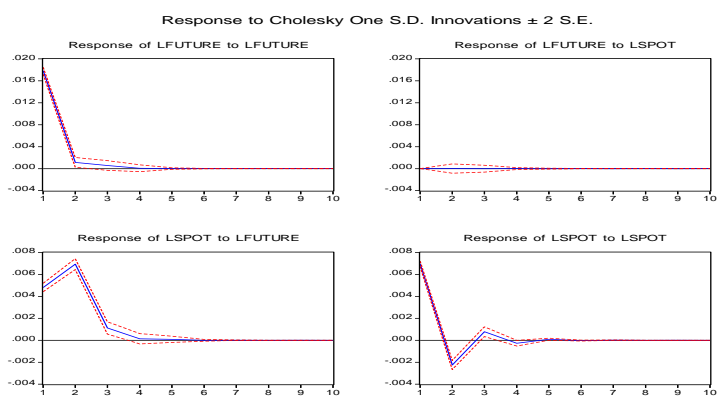

Fig. IV. Impulse Response Function of Pepper It is evident from the shape of the impulse response graphs that spot market has a larger response to one standard deviation shocks to the future price than the future responses to spot innovations .Initially the response of spot price to shocks to futures prices increased till $2^{\text {nd }}$ period .From $2^{\text {nd }}$ to $3^{\text {rd }}$ period it decreased sharply. It further declined till $4^{\text {th }}$ day .It remain almost constant from 4 to $10^{\text {th }}$ day . On the other hand, response of futures price to shocks to spot prices increased a bit initially declined till $4^{\text {th }}$ period and then remained constant. The response of spot price is higher than the response of future prices comparatively. Thus, it can be concluded from the analysis that future price leads in Pepper.

Table -VI: Variance Decomposition of Pepper

\begin{tabular}{|c|c|c|c|c|c|}
\hline \multicolumn{2}{|c|}{$\begin{array}{c}\text { Panel A: Variance } \\
\text { Decomposition of LSPOT: }\end{array}$} & \multicolumn{3}{c|}{$\begin{array}{c}\text { Panel B:Variance } \\
\text { Decomposition of } \\
\text { LFUTURE: }\end{array}$} \\
\hline Period & LFUTURE & LSPOT & Period & LFUTURE & LSPOT \\
\hline 1 & 32.22369 & 67.77631 & 1 & 100 & 0 \\
\hline 10 & 57.15507 & 42.84493 & 10 & 99.99993 & $7.32 \mathrm{E}-05$ \\
\hline
\end{tabular}

Panel A of Table $\mathrm{V}$ shows the forecast error variance decomposition of spot return. Initially a high percentage $(67.77 \%)$ of its total forecast error variance is explained by itself. After that it decreased to $42.96 \%$ and then remained constant. In the first period of the forecasting horizon $32.22 \%$ variation in the forecast error of spot market is explained by the futures market then it increased to $57.03 \%$ afterwards it remained constant. Similarly, Panel B of Table VI reports the forecast error variance decomposition of futures returns. Throughout the forecast period, future price explains a high level of forecast error variance of itself. Initially, it explains $100 \%$ variation in its forecast error by itself, but after that it stablized at $99.99 \%$. Hence we can say that in case of pepper future price leads spot price.

\section{EMPIRICAL RESULTS AND DISCUSSIONS}

The Government noticed price rise in six certain agricultural commodities (chana, soyabean, soyarefined and Pepper). (2012,Business Line).There are price rise and heavy fluctuations in these commodities future prices. These commodities were selected for the study and an analysis of cointegration and price discovery being conducted on these commodity. Johansen's Cointegration technique followed by the impulse response and variance decomposition was applied in selected Agricultural commodity to investigate the price discovery between spot and futures market. The empirical analysis was conducted for the daily data for near future market from November 2006 to April 2016. Using Augmented Dickey-Fuller test, we found enough evidence for the presence of a unit root for all 6 commodities spot and future prices initially. After first difference prices future and spot prices were stationary.We have also used the theory of cointegration to examine the long-run causal effect between spot and future markets of selected agricultural commodities. We found presence of single cointegration vector between the daily spot and one-month near futures commodity prices of chana,soyabean,soya oil,pepper, We could not not find any cointegration in Guar gum and Potato Future and spot prices.This is consistent with market efficiency. Finally, impulse response and variance decomposition test are used to measure impact of shocks in four commodities (chana, soyabean, soya oil, pepper) .The evidence shows that future leads to spot in case of soya oil and soyabean. Impulse response and variance decomposition, points out that futures leads to spot market and therefore futures prices can be used for pricing spot market transactions in Chana, Soyaoil, Soyabean and Pepper. Overall, we find evidence of price discovery taking place in these selected futures market, but efficient arbitrage is missing due to which error correction process is slow. Instead of suspending trading for these selected agricultural commodities. Steps need to be taken to make market more transparent and efficient. 


\section{REFERENCES}

1. Bisen Nidhi Rajendra, Ashtikar Rajiv G., A study on existing literature of commodity market, International Journal of Management Studies Vol. III ,Issue -1, June 2016

2. Biswas, S., \& Rajib, P. (2011). Testing price volume relationships for Indian commodity futures, Journal of Indian Business Research Vol.3 No. 2, pp.117-131

3. Chakraborty Ranajit and Das Rahuldeb (2013),Dynamic relationship between futures trading and spot price volatility: evidence from Indian commodity market, The IUP Journal of Applied Finance,Vol.19,No.4

4. Debashish Sathya Swaroop (2009), Effect of future trading on spot price volatility: evidence for NSE Nifty using GARCH, The journal of Risk Finance,Vol.10 Iss 1 pp.67-77

5. Kumar Vivek(2015).Futures Market of Pepper in India: An Empirical Study, International Journal of Applied Research pp.580-590

6. Malhotra Meenakshi and Sharma Dinesh Kumar (2013),Efficiency of guar seed futures market in India: an empirical study, The IUP Journal of Applied Science Vol.19,No.2

7. Naresh G , Thiyagarajan S \& Mahalakshmi S (2015), Price Gouging of Futures on Commodity Indices in India, The IUP Journal of Financial Risk Management Vol.XII, No. 2

8. Rao VCS , Rao GVK (2014),An insight into chilli cultivation and risk management procedures with special reference to Karnataka and Andhra Pradesh, Int. J. Business and Admin. Res. Rev, Agricultural Finance Review Vol. 75 No. 3, 2015 pp.416-431

9. Sharma Dinesh Kumar Malhotra Meenakshi (2015),Impact of futures trading on volatility of spot market of guar seed , Agricultural Finance Review Vol. 75 No. 3, pp.416-431

10. Sharma Tanushree, (2016) "The impact of future trading on volatility in Agriculture commodity: A case of Pepper.", The IUP Journal of Financial Risk Management, Vol. XIII, No. 4

11. Soni Tarun(2014), Integration linear and non-linear causality analysis using agriculture futures, Journal of Agribusiness in Developing and Emerging Economies Vol .4 No.2104 pp.157-171

12. Kumar,Acharya \& Suresh Babu Debashis, Price discovery and volatility spillovers in futures and spot commodity markets, Journal of Advances in Management Research Vol.11 Issue 2 pp.211-226

13. Thiagu Ranganathan \& Usha Ananthakumar, Market efficiency in Indian Soybean futures markets, International Journal of Emerging Markets,Vol. 9 Issue 4, pp.520-534

\section{AUTHORS PROFILE}

Dr. Tanushree Sharma - Associate Professor, Department of Commerce, School of Business \& Commerce, Manipal University Jaipur

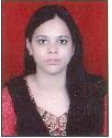

Ms. Puja Sharma - Research scholar, Department of Commerce, School of Business \& Commerce , Manipal University Jaipur 